\title{
STRENGTH BEHAVIOUR OF FOUNDRY SAND ON MODIFIED HIGH STRENGTH CONCRETE
}

\author{
Jayachandra ${ }^{1}$, Shashi kumar. ${ }^{2}$, Sanjith.J ${ }^{3}$, DG.Narayana ${ }^{4}$ \\ ${ }^{1}$ Post Graduate student, Department of Civil Engineering, S.J.C.I.T, chickballapura, Karnataka, India \\ ${ }^{2}$ Assistant Professor, Department of Civil Engineering, S.J.C.I.T, chickballapura, Karnataka, India \\ ${ }^{3}$ Assistant Professor, Department of Civil Engineering, A.I.T, chickmagaluru, Karnataka, India \\ ${ }^{4}$ Professor \& Head of Department of Civil Engineering, S.J.C.I.T, chickballapura, Karnataka, India
}

\begin{abstract}
Metal foundries use a large amount of sand as part of the metal casting process. Foundry industries generally recycle and reuse the used foundry sand many times in casting process. When the sand can no longer be reused in the foundry, it is removed from the foundry and is termed as "foundry waste sand." Like many waste products, foundry sand has beneficial applications to other industries. A mixture of silica sand coated with a thin film of burnt carbon and residual binder with traces of dust is termed as foundry sand. From the previous available literature it was found that replacement of sand by foundry sand by certain initial percentages gives a marginal increase in hardened properties of normal strength concrete.
\end{abstract}

In the present work, fine aggregate is replaced by foundry sand with percentages and tests were performed for hardened properties of modified high strength concrete for all replacement levels.

Keywords: Waste Foundry Sand, physical properties, chemical properties, compressive strength, splitting tensile strength and flexural strength

\section{INTRODUCTION}

The main constituents of foundry sand are high quality silica of uniformly sized or the lake sand obtained by mould of ferrous and nonferrous metal casting. Initially the sand will be clean before casting, but after casting, it will be rich in ferrous content of about $95 \%$ of its own volume. The major production of foundry sand is by automotive industry and by casting of generator parts.

The most popular and efficient process of casting process in industry is sand casting system. Green sand type is common sand type used for preparing the moulds for ferrous casting. The main constituents of green sand is high quality silica and bentonite clay (about $10 \%$ as binder), water present sea coal (good casting finisher of about 2 to 5\%).The type and volume of materials used for moulds depend upon the type of metal being casted in the mould, but usually the green sand owning the $90 \%$ of the about ingredients is used in large scale.

The chemically bonded sand cast system is used in addition to green sand casting system, which involves the implementation of one or more organic binders in addition with catalysts and different hardening or setting procedure. For providing the cavities in the moulds of non ferrous casting proves to be impractical to produce, hence the above mixture of $97 \%$ in foundry sand is generally used with chemically bonded system known as "cores". Every year about 10 to 15 million tons of foundry waste is produced in United States which includes dust and spent foundry sand.
Usually 1 ton of foundry sand is required to produce 1 ton of steelcasting.

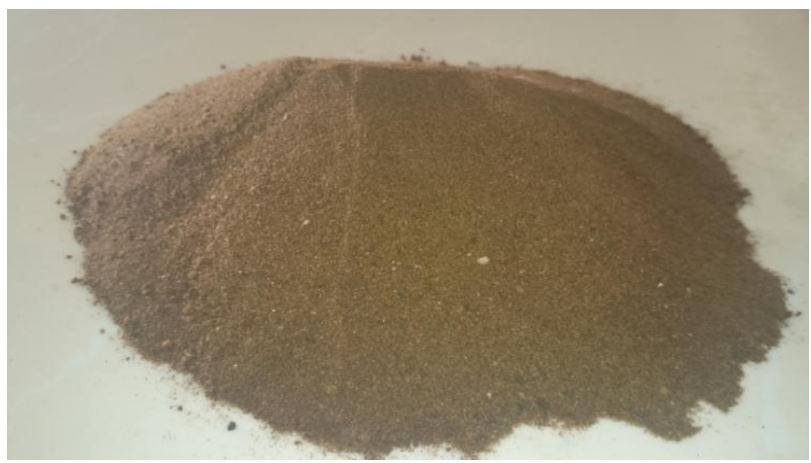

\subsection{Physical Properties}

Foundry sand is uniformly graded consisting of about 85 to $90 \%$ of material ranging from $0.6 \mathrm{~mm}$ to $0.15 \mathrm{~mm}$ (No 30 sieve) and rest of the foundry sand is believed to be finer than $0.075 \mathrm{~mm}$ (No.200 sieve). The grains are of round and sub-angular shaped, but not of angular. However the foundry sand is too fine compared to that of fine aggregate in grading. Spend foundry sand exerts low water absorption and poor plastic property. Water absorption is noted to vary widely depending upon the presence of binders and additive, mainly the presence of organic impurities by sea coal binder system can cause hike in water absorption. This may limit its application in various fields such in concrete works. Foundry sand's Specific gravity range from 2.39 to 2.55 . The specific gravity depends upon the quantity of fines and 
additives present in the foundry sand and on also of its moisture content if it is less than $2 \%$. While molding the large number of clay lumps are formed which are disintegrated easily during the tests.

Table 1.1 Typical physical properties of spent green foundry sand

\begin{tabular}{|l|l|l|}
\hline Property & Results & Test Method \\
\hline Specific Gravity. & 2.50 & ASTM D854 \\
\hline $\begin{array}{l}\text { Bulk Relative Density, } \\
\mathrm{kg} / \mathrm{m}^{3}\end{array}$ & $\begin{array}{l}2590 \\
(160)\end{array}$ & $\begin{array}{l}\text { ASTM } \\
\text { C48/AASHTO T84 }\end{array}$ \\
\hline Absorption, \% & 0.40 & ASTM C128 \\
\hline Moisture Content, \% & 6.4 & ASTM D2216 \\
\hline $\begin{array}{l}\text { Clay Lumps and Friable } \\
\text { Particles. }\end{array}$ & 10 & $\begin{array}{l}\text { ASTM } \\
\text { C142/AASHTO } \\
\text { T112 }\end{array}$ \\
\hline $\begin{array}{l}\text { Coefficient of } \\
\text { Permeability (cm/sec). }\end{array}$ & $10^{-4}$ & $\begin{array}{l}\text { AASHTO } \\
\text { T215/ASTM D2434 }\end{array}$ \\
\hline Plastic limit/plastic index. & Nonplastic & $\begin{array}{l}\text { AASHTO } \\
\text { T90/ASTM D4318 }\end{array}$ \\
\hline
\end{tabular}

\subsection{Chemical Properties}

Silica sand coated with thin film of burnt carbon all around predominates in spent foundry sand; it also contains a binder which could be either bentonite or sea coal or resins and dust. By X-ray fluorescence method the chemical composition of the spent foundry sand is determined and it is shown below.Silica sand is adhesive in nature, which attracts water to surface and hydrophilic, which do not dissolve in water. This property can make it vulnerable to stripping off in layer from an single solid unit when it is used for road construction or as such use like runway, taxiway construction subjected to abrasive forces. Hence anti-stripping agents are utilized to minimize such ill effects. The $\mathrm{pH}$ value of foundry sand is found to be 4 and it depends on the binder used for type of metal cast. The foundry sand cannot be used for Reinforced cement concrete works since it can corrode the metal. The presence of phenol can be a major problem if it percolates to a main stream of ground water supplies, which will if the surface is subjected to heavy precipitation causing the washable fractions to leach out through stock piles. Hence the phenol discharge must be monitored frequently to assess the phenol discharge.

Table 1.2 Chemical oxide composition in Foundry sand

\begin{tabular}{|l|l|}
\hline Constituent & Value $(\%)$ \\
\hline $\mathrm{SiO}_{2}$ & 87.93 \\
\hline $\mathrm{Al}_{2} \mathrm{O}_{3}$ & 4.70 \\
\hline $\mathrm{Fe}_{2} \mathrm{O}_{3}$ & 0.94 \\
\hline $\mathrm{CaO}$ & 0.12 \\
\hline $\mathrm{MgO}$ & 0.30 \\
\hline $\mathrm{SO}_{3}$ & 0.09 \\
\hline $\mathrm{Na}_{2} \mathrm{O}$ & 0.19 \\
\hline $\mathrm{K}_{2} \mathrm{O}$ & 0.21 \\
\hline
\end{tabular}

\begin{tabular}{|c|c|c|c|}
\hline $\mathrm{TiO}_{2}$ & 0.15 & & \\
\hline $\mathrm{P}_{2} \mathrm{O}_{5}$ & 0.00 & & \\
\hline $\mathrm{Mn}_{2} \mathrm{O}_{3}$ & 0.06 & & \\
\hline $\mathrm{SrO}$ & 0.03 & & \\
\hline LOI & $\begin{array}{l}5.15 \quad(0.45 \\
2.1-12.1\end{array}$ & to & 9.47) \\
\hline TOTAL & 99.87 & & \\
\hline
\end{tabular}

\section{COMPRESSIVE STRENGTH}

The compressive strength was obtained by testing $100 \times 100 \times 100 \mathrm{~mm}$ cubes. The curing is maintained for 7,14 and 28days. The tests were confirming to BS 1881: part 116 (1983).It has been found that $25 \%$ replacement of fine aggregate showed a furtherance results.

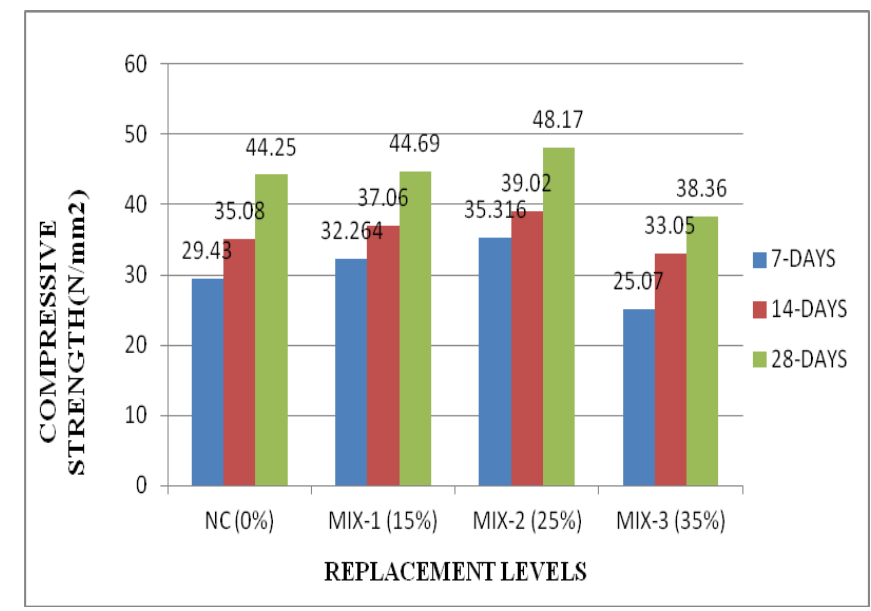

Chart -1: Compressive strength study for different replacement levels

\section{SPLITTING TENSILE STRENGTH}

It is carried out for different cylindrical specimens confirming IS 5816:1959 for curing period of 7days, 14days and 28days strength of mixes with $0 \%, 15 \%, 25 \%$ and $35 \%$ replacement show in below chart 2 . It has been found that $25 \%$ replacement of fine aggregate showed a refinement in tensile strength.

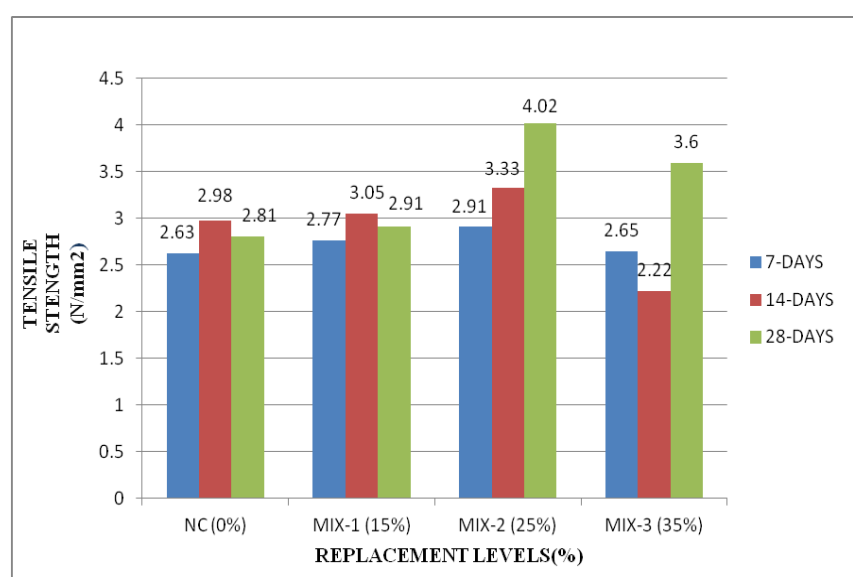

Chart 2: splitting tensile strength for different replacement levels 


\section{FLEXURAL STRENGTH}

Flexural Strength test for various mixes at different curing period were done for short beams confirming to IS 516:1959. For $25 \%$ of replacement the enhancement of flexural strength is observed.

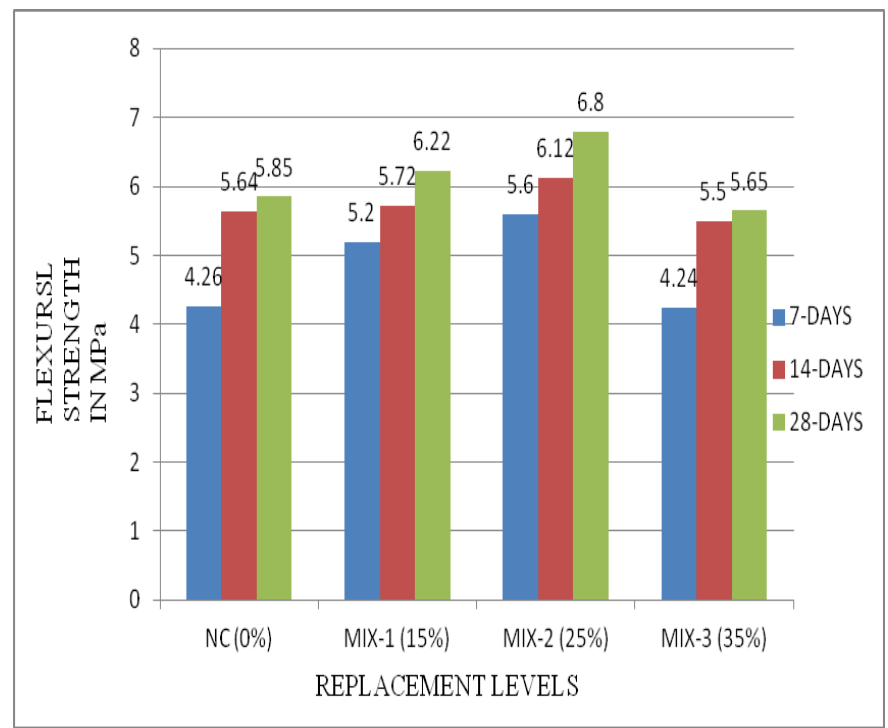

Chart 3: flexural strength for different replacement levels

\section{CONCLUSION}

It could be noted that the effects of concrete containing foundry sand is unique, as the foundry sand changes its physical and chemical properties and also its manufacturing process. Instead of using it for land filling it can be used more effectively and efficiently for construction.

The intrusion of foundry sand reduces workability and also requires more water to form a homogeneous mix. Annexation of foundry sand helps in enhancing the hardened properties of concrete to a margin of $25 \%$.

\section{ACKNOWLEDGEMENTS}

I am thankful to Mr. Shashi kumar.A ,Mr.Sanjith.J and Dr. $\mathrm{G}$ Narayana for their guidance. I also thank department civil engineering S J C Institute of technology, chickaballapur. And last but not the least my dear friends who have supported me to complete this work.

\section{REFERENCES}

[1]. Tarun R. Naik, Viral M. Patel, Dhaval M. Parikh, Mathew P. Tharaniyil, "Utilisation of used foundry sand in concrete", Journal of Materials in Civil Engineering, Vol. 6, No. 2, May, 1994.

[2]. Johnny Bolden, Taher Abu-Lebdeh and Ellie Fini, "Utilization of recycled and waste materials in various construction applications", American Journal of Environmental Science, 9 (1), ISSN: 1553-345X, Pg.14-24, 2013.

[3]. J.M. Khatib, B.A. Herki, S. Kenai, "Capillarity of concrete incorporating waste foundry sand", Elsevier, Construction and Building Materials 47 (2013) 867-871.
[4]. Sohail Md, Abdul Wahab, Arfath Khan Md. "A Study on the Mechanical Properties of Concrete by Replacing Sand with Waste Foundry Sand"(ISSN 2250-2459, ISO 9001:2008 Certified Journal, Volume 3, Issue 11, November 2013)

[5]. Carnin R. L. P. et al."Use of an integrated approach to characterize the physicochemical properties of foundry green sands". ThermochimicaActa543 (2012) 150- 155. Published by Elsevier B.V- 012.

[6]. Khatib J.M., Baig. B., Menadi B, Kenai S. "Waste Foundry Sand Usage In Concrete". Innovation \& Valorization in Civil Engineering \& Construction Materials2011.

[7]. Rafat Siddique, Geert de Schutter, Albert Noumowe "Effect of used-foundry sand on the mechanical properties of concrete" https://www.elsevier.com/locate/conbuildmat Construction and Building Materials 23 (2009) 976-980.

[8]. Eknath P. Salokhe, D.B.Desai, "Application of Foundry Waste Sand In Manufacture of Concrete" IOSR Journal of Mechanical and Civil Engineering (IOSR-JMCE) ISSN: 2278-1684, PP: 43-48

[9]. Pathariya Saraswati C, Rana Jaykrushna K, Shah Palas A, Mehta Jay G, Patel Ankit N, " Application of Waste Foundry Sand for Evolution of Low-Cost Concrete" International Journal of Engineering Trends and Technology (IJETT) - Volume 4 Issue 10 - Oct 2013

\section{BIOGRAPHIES}

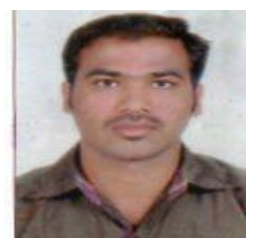

Mr. Jayachandra is having his bachelor's degree in civil engineering from V.T.U, Belgaum and he is currently pursuing his masters in structural engineering from $\mathrm{S}$ J C Institute of Technology, Chickaballapur.

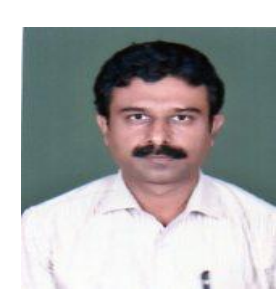

Mr.Shashi kumar.A, Assistant Professor , Department Of Civil Engineering, S.J.C. Institute of Technology, Chickaballapur. He has wide experience in teaching of 15 years and he is currently pursuing his ph.D under which he is investigating flexural behavior of R.C beams by incorporating foundry sand as partial replacement of natural sand.

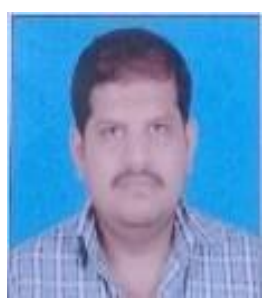

Mr.sanjithJ, Assistant Professor ,Department Of Civil Engineering, Adhichunchanagiri Institute of Technology, Chikmagaluru, he is currently pursuing $\mathrm{PhD}$ with a wide experience in the field of Structural engineering in both academic and research. He has published over 21 technical papers in national, international journals and conferences. His research interest includes structural concrete, soil structure interaction, seismic analysis etc. $\mathrm{He}$ has eight professional memberships in technical bodies. 
DR. G Narayana, Professor and Head of Civil engineering department, S J C Institute of Technology, Chickaballapur, have a wide experience in teaching and research in the field of Structural engineering. He is also a structural designer, consultant for many projects. 